\title{
PÓŁWYSEP BAŁKAŃSKI JAKO OBSZAR DZIAŁAŃ MILITARNYCH PODCZAS WOJEN BAŁKAŃSKICH. CHARAKTERYSTYKA GEOGRAFICZNO-WOJSKOWA
}

\author{
ANDRZEJ KRZAK
}

\begin{abstract}
Andrzej Krzak, Półwysep Bałkański jako obszar działań militarnych podczas wojen bałkańskich. Charakterystyka geograficzno-wojskowa (Balkan peninsula as the area of military operation during Balkan wars. Geographical-military characteristics).
\end{abstract}

Balcanica Posnaniensia. Acta et studia, XIX, Poznań 2012, Wydawnictwo Instytutu Historii UAM, pp. 149-168, ISBN 978-83-63-047-17-7, ISSN 0239-4278. Polish text with a summary in English.

Andrzej Krzak, Uniwersytet Szczeciński, Wydział Humanistyczny, Katedra Badań nad Konfliktami i Pokojem.

\section{Wstęp}

Mianem Bałkany lub Półwysep Bałkański zwykło się określać obszar obejmujący południowo-wschodnią część Europy zawierającą się między czterema morzami: Czarnym od wschodu, Adriatyckim i Jońskim od zachodu oraz na południu Egejskim ${ }^{1}$. O ile nie ma problemu z wytyczeniem granic na zachodzie i południu, to w odniesieniu do północnej i wschodniej granicy Półwyspu występują znaczne trudności. Należy zauważyć, że na przestrzeni wieków zarówno geografowie, jak i politycy inaczej określali granice Bałkanów oraz ich nazewnictwo. Jeśli przyjmowali kryteria geograficzne, to różnice należy uznać za nieznaczące, natomiast gdy problem był ujmowany wg kryterium politycznego, to bywały one znacznie większe.

Jak już wspomniano, szczególnie poważnym problemem jest wytyczenie granic północnych i północno-zachodnich Półwyspu. W zasadzie przyjmowano, że granicę północną tworzy dolny bieg Dunaju do jego ujścia do Sawy. Serbski historyk i geograf Jovan Cvijić granicę północną kreśli od Triestu poprzez Bramę Postojny² doli-

\footnotetext{
${ }^{1}$ H. Batowski, Bałkany, kraje i narody bałkańskie, „Etnografia Polska”, T. X, 1966, s. 116.

2 Brama Postojna (Brama Adriatycka lub Włosko-Illiryjska) jest jedną z głównych przełęczy pasma dynarskiego. Znajduje się w Słowenii, Regio Carsica Militaris, http://www.parkvojaskezgodovine.si/ regio_carsica_militaris/eng/kronologija.html, [dostęp: 2 września 2012].
} 
ną Sawy aż po Dżerdap ${ }^{3}$ kończąc na delcie Dunaju ${ }^{4}$. Z kolei prof. M. Waldenberg uważa, że zachodnią granicę stanowi wybrzeże Adriatyku do Rijeki (Fiume), a nawet do Zatoki Triesteńskiej5. Dyskusyjną kwestią pozostaje to, czy zaliczamy do Bałkanów: Słowenię, Węgry oraz Rumunię w ujęciu całościowym. Pogląd prof. M. Waldenberga, że Węgry oraz północna Rumunia nie wchodzą w obręb terytorialny Półwyspu Bałkańskiego, wydaje się tylko częściowo słuszny. Jeśli będziemy te państwa traktować jako jednostki stanowiące część Europy Środkowo-Wschodniej oraz Bałkanów ${ }^{6}$, to obszar Rumunii należy zaliczyć zarówno do jednej jak i drugiej części Europy. Należy się natomiast zgodzić z poglądami prof. M. Waldenberga odnoszącymi się do Węgier. Pomimo że Węgry na południu graniczą z państwami bałkańskimi, to nie można ich w żadnym wypadku łączyć z tym obszarem, nawet jeśli w przeszłości granice polityczne i kulturowe obejmowały krainy i państwa dzisiaj zaliczane do Bałkanów. Prof. H. Batowski uważa natomiast, że jeśli chodzi o terytorium Rumunii, to jego część, a mianowicie Dobrudża ${ }^{7}$, wchodzi w skład Półwyspu ${ }^{8}$. Wspomniany już serbski geograf J. Civić wyraża podobne poglądy zaliczając część Rumunii, a właściwe tzw. Donje Podunavlje oraz europejską Turcję do Płw. Bałkańskiego?.

Podobne trudności występuja z określeniem przynależności Słowenii, ponieważ według większości poglądów terytorium tego państwa, podobnie jak Węgier, nie wchodzi w obszar Półwyspu Bałkańskiego.

Jeszcze inne podejście prezentuje $\mathrm{w}$ jednym ze swoich artykułów dr Jerzy Stańczyk. Przedstawia on argumenty i poglądy historyków oraz politologów przypisujących zarówno Słowenię, jak również Chorwację, Rumunię i Bułgarię do regionu Europy Środkowo-Wschodniej ${ }^{10} \mathrm{i}$ zarazem do Bałkanów. Z kolei Jan Kofman, nie rozróżniając granic pomiędzy Europą Środkową a Bałkanami, uważa, że Europa Środkowo-Wschodnia obejmuje wszystkie kraje bałkańskie oraz Polskę, Czechy,

${ }^{3}$ Dżerdap/Iron Gates (rum. Portile de Fier; serb. Ђердапска клисура, Đerdapska Klisura; Żelazne Wrota), przełom (dolina) Dunaju oddzielający Karpaty od Gór Wschodnioserbskich stanowi granicę między Rumunią i Serbią, A. Maryański, Rumunia, Warszawa 1973, s. 37-38; P. Burchard, Rumunia, Warszawa 1968, s. 83-87.

${ }^{4}$ M. Tešić, Geostrategijskij položaj Balkana (Položaj Jugoslavije na Mediteranu), [w:] Balkan krajem 80-ih godina, Beograd 1987, s. 79.

${ }^{5}$ M. Waldenberg, Narody zależne i mniejszości narodowe w Europie Środkowo-Wschodniej. Dzieje konfliktów i idei, Warszawa 2000, s. 15.

${ }^{6}$ Granice Bałkanów i Europy Środkowo-Wschodniej nie są jednolite. Leszek A. Kosiński uważa, że do Europy Środkowo-Wschodniej należy zaliczyć Rumunię, Jugosławię (kraje powstałe po rozpadzie tego państwa), Bułgarię i Albanię. Inni naukowcy dodają nawet Turcję i Grecję, Ibidem, s. 14-15.

7 Począwszy od 1878 r. Rumunia rywalizował o Dobrudżę z Bułgarią. W 1913 r. w wyniku II wojny bałkańskiej (zwanej również międzysojuszniczą) Rumunia uzyskała tę prowincję aby ja ponownie dwukrotnie stracić w wyniku działań I i II wojny światowej. Jednak zarówno po Wielkiej Wojnie jak i po kolejnym światowym konflikcie Dobrudża z powrotem była przyznawana Rumunii.

${ }^{8}$ H. Batowski, Zagadnienia Bałkańskie, Kraków 1939, s. 4.

${ }^{9}$ M. Tešić, Geostrategijskij položaj Balkana..., s. 79.

${ }^{10}$ J. Stańczyk, Europa Środkowa - kryteria wyodrębniania i cechy regionu, „Studia polityczne”, nr 12/2001, s. 199-200. 
Słowację, Austrię, Węgry a także Łotwę, Litwę i Estonię ${ }^{11}$. Wyodrębnienie regionu Europy Środkowej (lub Środkowo-Wschodniej) i wchłonięcie Europy PołudniowoWschodniej obejmującej Półwysep Bałkański, wydaje się być jednak zbyt szerokie, zarówno z geograficznego, politologicznego, jak również historycznego punktu widzenia. Z kolei wg poglądów Jerzego Tomaszewskiego, należy oddzielić obszary dawnej monarchii habsburskiej od terytorium, które znajdowało się pod panowaniem Imperium Ottomańskiego, czyli Europę Południowo-Wschodnią ${ }^{12}$.

Aby jednak, móc precyzyjnie opisać dzieje militarne lub polityczne Bałkanów, nie można pozwolić sobie na pominięcie ogólnego przynajmniej scharakteryzowania terytorium Rumunii oraz Słowenii.

Największy problem w określeniu, które z państw (jakie terytoria i obszary) wchodzą w skład Półwyspu, stanowi jego budowa, bowiem jest on tak zrośnięty z resztą kontynentu, że bardzo trudno jest wyznaczyć jakiś jeden element integrujący. Każdy więc podział lub zaproponowana linia rozgraniczenia mogą mieć jedynie umowny charakter. Warunki geograficzne i układ półwyspu obszar ten dezintegrują. Dlatego też wobec poważnych różnic poglądów co do przebiegu północnej granicy Bałkanów należy przyjać, że będzie nią linia Dunaju - Sawy i Kupy oraz rumuńska Dobrudża. Terytorium Słowenii oraz północna i wschodnia częśc Rumunii powinny być natomiast rozpatrywane raczej w kontekście wydarzeń politycznych, a nie położenia geograficznego.

Interesy krajów leżących w bezpośredniej styczności z państwami bałkańskimi prowadziły do zmian politycznych, w tym i terytorialnych. W przypadku Rumunii możemy mówić raczej o państwie „o interesach bałkańskich”. Aby poprawnie określić zakres terytorialny Półwyspu Bałkańskiego, należałoby mówić o krajach bałkańskich, a nie o państwach. Wówczas można byłoby zastosować szerszy zakres pojęciowy ${ }^{13}$.

Istotną kwestią w trakcie sporządzania opisu geograficznego krajów Półwyspu Bałkańskiego są zmieniające się granice oraz nowo powstałe państwa na przestrzeni ostatniego stulecia. Znaczne zmiany geograficzno-polityczne (jak również militarne) na Bałkanach przyniosła ostatnia dekada XX wieku w związku z rozpadem Jugosławii.

Kolejny dylemat stanowi nazwa Półwyspu: Bałkański oraz utożsamiane z nim pojęcie: Bałkany. Należy przyjąć, że obie nazwy są poprawne. Jednak pojęcie Półwyspu Bałkańskiego może odnosić się zarówno do jednostki geograficznej jak i całościowego układu polityczno-geograficznego omawianego obszaru. Z kolei nazwa Bałkany stanowi bardziej ogólne określenie. Dotyczy to zarówno kwestii geograficznych jak również politycznych. Wyraz Bałkany jest pochodzenia tureckiego i odnosi się do słowa Balkan, oznaczającego pasmo górskie pokryte lasami. Jak stwierdził H. Batowski, Turcy, którzy w XIV w. zajęli część tego obszaru nadali mu nazwę od charakterystycznych dla tego regionu lesistych gór. Co ciekawe, w opisach terenu stosowali ra-

\footnotetext{
11 Ibidem.

12 Ibidem.

${ }^{13}$ Kwestie te szerzej poruszał prof. H. Batowski, H. Batowski, Bałkany, kraje i narody..., s. 121.
} 
czej liczbę mnogą wyrazu Balkan, czyli Balkanar ${ }^{14}$. Nazwa ta była jednak używana w całościowym ujęciu. Natomiast terminem polityczno-administracyjnym, jakim posługiwali się Turcy, była nazwa Rumelia odnosząca się do państwa wschodniorzymskiego. Termin Bałkany w odniesieniu do pasma górskiego występuje również w języku starogreckim oraz łacińskiego. Odpowiednio dla nowogreckiego Chersonisos tu Emu oraz dla łaciny Haemus ${ }^{15}$.

Określenie Pótwysep Bałkański po raz pierwszy zostało użyte na początku XIX w. przez niemieckiego geografa A. Zeune ${ }^{16}$. Nieco później pojawiło się pojęcie Bałkany. Według prof. Tomasza Witucha nazwę tę do języka francuskiego wprowadził w połowie XIX w. geograf i podróżnik austriacki Ami Boué. Definitywne utrwalenie tego pojęcia w języku niemieckim jest natomiast zasługą geografa i etnografa, Felixa Kanitza ${ }^{17}$.

\section{Charakterystyka geograficzna Półwyspu Bałkańskiego}

Trójkąt Półwyspu Bałkańskiego obejmuje około $550000 \mathrm{~km}^{2}$ o długości ok. $950 \mathrm{~km}$, szerokości na północy $1260 \mathrm{~km}$. W przeważającej części jest to obszar górzysty, składający się z szeregu krain o zróżnicowanym charakterze pod względem rzeźby terenu, klimatu, sieci hydrograficznej, gleby, flory i fauny oraz stosunków społecznych.

Półwysep Bałkański jeden z trzech wielkich półwyspów Europy Południowej, stanowi naturalny pomost pomiędzy Europą a Azją. Opisując jego ukształtowanie należy podzielić go umownie na dwie części: północną i południową. Część północna to obszar rozciagający się od Morza Czarnego na wschodzie do wybrzeży Morza Adriatyckiego na zachodzie, opierający się o północą granicę półwyspu. Południową natomiast część tworzą półwyspy: Grecki, Chalcydycki i Gallipoli. W południowo-wschodniej części Półwysep Bałkański jest oddzielony od Azji cieśninami Bosfor i Dardanele. Posiada dobrze rozwiniętą linię brzegowa, zwłaszcza na kresach zachodnich (wybrzeże M. Adriatyckiego). Dzięki czemu na całym wybrzeżu występują liczne zatoki, w których lokowano osady i miasta. Do zatok mających najistotniejsze znaczenie geograficzno-wojskowe zaliczamy:

- w odniesieniu do Adriatyku: Triesteńską, Fiumska, Splitska, Drinu i Kotorską ${ }^{18}$;

- Duressi (Durazzo), Krawastańską i Vlora występujące na adriatyckim wybrzeżu Albanii;

14 Ibidem, s. 118.

15 Ibidem, s. 119.

16 D. T. Bataković, Il mosaico Balcanico fra Realpolitik e escontro di civiltá, “Limes”, „Rivista Italiana di Geopolitica”, Vol. 3/1995, s. 74-77; F. Gołembski, Bałkany. Determinanty stabilności, Warszawa 1982, s. 51, Vide.: A. Zueune, Versuch einer wissenschaftlichen Erdbeschreibung Gea, Berlin 1809.

17 T. Wituch, Bałkany-szkic definicji, „Dzieje Najnowsze”, R. XXX, nr 2/1998, s. 136.

${ }^{18}$ Dragoš D. Kostich, The Land and People of the Balkans. Albania Bulgaria Yugoslavia, PhiladelphiaNew York 1973, s. 38. 
Wybrzeże greckie także pokryte jest licznymi zatokami ${ }^{19}$. Na zachodnim wybrzeżu usytuowana jest Zatoka Arkadii, natomiast na południu Messeńska i Lakońska. Z kolei we wschodniej części Morza Egejskiego występuje zatoka Nauplia, Sarońska, która łączy się z Zatoką Koryncką ${ }^{20}$. W głąb Grecji kontynentalnej wcinają się zatoki: Lamis, Pagassitikos i Salonicka, natomiast na Półwyspie Chalcydyckim-Kassandra, Hagion Oros, Ierission i Orfanon i na końcu koło Półwyspu Gallipoli - zatoka Soros. Po europejskiej stronie Morza Marmara zatoki nie występują.

Na zachodnim wybrzeżu Morza Czarnego możemy wyodrębnić trzy większe zatoki: u wybrzeży bułgarskich Warneńską i Burgaską zaś u ujścia Dunaju - Lacal.

Pod względem geograficznym do Półwyspu należy znaczna ilość wysp. Są one Głównie usytuowane są przy wybrzeżach: adriatyckim i egejskim Na północy, na Morzu Adriatyckim występuje grupa wysp krasu chorwackiego: Krk, Lusin i Rab, następnie w środkowej części, zwanej welebicką, znajdują się wyspy: Pag, Maun, Vir, Silba, od której począwszy w kierunku południowym ciągnie się pas kilku tysięcy wysp i wysepek wybrzeża dalmatyńskiego. Największe z nich to: Brač, Hvar, Korčula, Miljet ${ }^{21}$. Na wybrzeżu albańskim prawie nie występują wyspy, z wyjątkiem Sazanit (wł. Saseno) u ujścia Zatoki Valońskiej (Zat. Vlora). Wyspa ta ma istotne znaczenie strategiczne dla szlaków komunikacyjnych Morza Adriatyckiego, bowiem stanowi naturalny punkt, z którego można kontrolować wyjście na Morze Jońskie i dalej na Morze Śródziemne. Z kolei wśród wysp greckich Morza Jońskiego możemy wyróżnić Korfu, Pervezę, Kefalonię i Zantę 2 . Natomiast na południe od Peloponezu znajduje się największa z wysp opisywanego obszaru, czyli Kreta oraz nieco wyżej położona Cytera. Te dwie wyspy oddzielają Morze Egejskie od Morza Śródziemnego. W tym rejonie szczególnie ważnym punktem strategicznym jest Kreta, dzięki której władające nią państwo może kontrolować szlaki wodne, jak i lotnicze na obszarze Azji Mniejszej, wschodniej części Morza Śródziemnego oraz północnego wybrzeża Bliskiego Wschodu. W południowej części Morza Egejskiego rozpościera się archipelag wysp zwanych Cykladami (220 wysp), z których do największych należy zaliczyć: Andros, Paros i Tinos. U wschodnich wybrzeży środkowej Grecji występuje Evvia (Eubea), a na północ od niej May oraz grupa wysp Sporad. Najbardziej na północ wysuniętymi wyspami Morza Egejskiego są: Lemnos, Evstratios, Tasos i Samotraki, zaś przedłużeniem Półwyspu Gallipoli jest wyspa Imroz ${ }^{23}$. Na Morzu Marmara występuje pewna ilość wysp, jednak przynależą one do azjatyckiej części wybrzeża. Z kolei u wybrzeży Bułgarii i Dobrudży na Morzu Czarnym nie występują wyspy.

19 Wielka Geografia Powszechna, Europa IV, Hiszpania, Portugalia, Włochy, Jugosławia, Bułgaria, Grecja, Albania, Turcja Europejska, red. S. Gorzuchowski, T. Dybczyński, Warszawa 1938, s. 4.

20 To połączenie wykorzystano przy budowie Kanału Korynckiego, o którym pisaliśmy powyżej.

21 Dragoš D. Kostich The Land and People of the Balkans..., op. cit., s. 41.

22 Wielka Geografia Powszechna, Europa IV, Hiszpania, Portugalia, Włochy, Jugosławia..., op. cit., s. 4.

23 Ibidem. 
Pod względem ukształtowania Półwysep jest bardzo zróżnicowany, z przewaga górzystej rzeźby terenu. Do linii Belgrad-Saloniki cała zachodnia część Bałkanów stanowi pas górski, który ciagnnie się wzdłuż wybrzeża Adriatyku aż do rzeki Drin w Albanii. Nosi on nazwę Gór Dynarskich, które przechodzą w pasmo Gór Albańsko-Greckich ${ }^{24}$. Góry te rozpadając się na mniejsze grupy, sięgają aż po Peloponez. Najwyższym szczytem Dynarów jest Durmitor położony w Czarnogórze (2 528 m n.p.m.), natomiast w Górach Albańsko-Greckich króluje mityczny Olimp.

Góry Dynarskie w południowej części łączą się z pasmem Škopskiej Cyrnej Gory i Šar Planiny, które oddzielają Macedonię i Kosowo, zamykając od południa Kosowo Polje. Najwyższym szczytem tego pasma jest Titov Vrh. Oba te pasma łączą Rodopy z Górami Dynarskimi ${ }^{25}$.

Góry Dynarskie, oddzielając wybrzeże dalmatyńskie od reszty Bałkanów, uniemożliwiają prowadzenie działań militarnych dużych zgrupowań wojsk zmechanizowanych. Wyjątek stanowi ujście i dolina Neretwy, które sąjednym z nielicznych punktów umożliwiających dostęp do wnętrza Półwyspu ${ }^{26}$ od strony Morza Adriatyckiego.

We wschodniej części Bałkanów znajdują się Góry Bałkańskie (pasmo Bałkanu), które stanowią południowe wygięcie wschodniego łańcucha Karpat. Góry Bałkańskie dzielą się na: Bałkan Zachodni, Średni i Wschodni. Najwyższym szczytem pasma jest Jurmukczal. Na południe od środkowej części Bałkanu występuje odrębne pasmo górskie zwane Antybałkanem ${ }^{27}$.

Pozostała część Półwyspu, na wschodzie od dopływu Morawy-Ibaru sięgając do wybrzeży Morza Czarnego oraz na południu do wybrzeży Morza Egejskiego, składa się z szeregu pasm i masywów górskich, do których zaliczmy Masyw Rodopski, ciągnący się na północ poprzez doliny: Maricy, Strumy, Wardaku, Nišu, Owczego i Kosowego Pola. Najwyższym jego szczytem jest Mus Allah ${ }^{28}$. Rodopy są górami kanalizującymi wszelki manewr i ruch, który na tym obszarze może się odbywać tylko dolinami rzek.

\section{Hydrografia}

Półwysep Bałkański poprzecinany jest licznymi rzekami spływającymi do trzech zlewisk: Morza Czarnego (Dunaj z Sawą, Morawa i Ister), Morza Egejskiego (Marica, Struma, Wardar) i w mniejszym stopniu do Morza Adriatyckiego (Drina, Neretwa).

24 Góry Albańsko-Greckie to wypiętrzenia fałdowe należące do epoki kredy i późniejszych wraz z niektórymi formami paleozoicznymi. Występują tu przede wszystkim skały fliszowe i wapienne, przeważnie o charakterze krasowym. Ogólnie należy przyjąć, że nie są to formy wysokie, Wielka Geografia Powszechna, Europa IV, Hiszpania, Portugalia, Włochy, Jugosławia..., op. cit., s.

${ }^{25}$ H. Batowski, Zagadnienia ..., op. cit., s. 4.

26 T. Wituch, Bałkany..., op. cit., s. 136.

${ }^{27}$ H. Batowski, Zagadnienia ..., op. cit., s. 5.

${ }^{28}$ Wielka Geografia Powszechna, Europa IV, Hiszpania, Portugalia, Włochy, Jugostawia..., op. cit., s. 4 . 
Stosunki wodne wewnątrz Półwyspu są zróżnicowane i uwarunkowane w zależności od rzeźby terenu. Głównym ciekiem wodnym Bałkanów jest Dunaj wraz ze swoimi dopływami. Cała północna cześć Półwyspu jest zasilana wodami tej rzeki oraz jej dopływami, a przede wszystkim Sawy. Do ważniejszych rzek należą: Kupa, Una, Vrbas, Bosna i Drina ${ }^{29}$, a ponadto Morawa, Timok, Ogost, Isker Osma, Jantra, które uchodzą do Dunaju. Dopływy Sawy i Dunaju w przeważającej części biorą swój początek w Górach Dynarskich, pozostałe zaś w masywie Bałkanów. Z kolei do Morza Adriatyckiego wpada niewiele rzek. Do najważniejszych zaliczamy: Krkę, Neretvę (Narentę), Cetinę, Drin, Szkumbin, Semeni, i Vijosë. Do zlewiska Morza Egejskiego należą natomiast: Sperchios, Salamorie (Peneios), Bistrica, Vardar, Struma, Mesta i Marica, z kolei do Morza Jońskiego wpadają: Aspropotamos (Achelós) i Ruphia $\left(\right.$ Alfeios ${ }^{30}$. Oprócz rzek na Półwyspie Bałkańskim występują również jeziora, choć ich liczba jest niewielka. Największe z nich to Jezioro Skutari (Škodra) ${ }^{31}$ i Ochrydzkie ${ }^{32}$, które jest rozdzielone granicą pomiędzy Macedoniąi Albanią. Na terytorium Chorwacji występują liczne jeziora krasowe $\mathrm{z}$ największą grupą położoną $\mathrm{w}$ pobliżu granicy z Bośnią i Hercegowiną, czyli Jeziorami Plitwickimi. Ponadto niewielkie zbiorniki znajdują się również w Grecji, w północnej części półwyspu Chalcydyjskiego oraz w Tracji. Również na terytorium Bułgarii spotykamy się z kilkoma większymi jeziorami usytuowanymi w Dobrudży i u wybrzeży Morza Czarnego.

\section{Komunikacja}

Przejściowe położenie Półwyspu sprawia, że od zarania dziejów jest on obszarem były obszarem znajdującym się w strefie ścierania się wpływów wielkich mocarstw dążących do opanowania cieśnin umożliwiających wyjście do Morza Śródziemnego oraz sprawowania kontroli nad najkrótszą drogą lądową z Europy do Azji ${ }^{33}$.

Od zachodu równolegle do wybrzeża adriatyckiego biegnie morski szlak komunikacyjny, który przez Cieśninę Otranto ${ }^{34}$ (zwężenie pomiędzy Półwyspem Apenińskim i Bałkańskim) wychodzi na Morze Śródziemne.

\footnotetext{
${ }^{29}$ Rzeki te znajdują ujście w Sawie.

30 Wielka Geografia Powszechna, Europa IV, Hiszpania, Portugalia, Włochy, Jugosławia ..., op. cit., s. 6.

31 Jezioro to jest również formą krasową.

${ }^{32} \mathrm{Z}$ jeziora Ochrydzkiego bierze swój początek Czarny Drin, Wielka Geografia Powszechna, Europa IV, Hiszpania, Portugalia, Włochy, Jugosławia..., op. cit., s. 6.

33 J. Ilić, M. Spasowski, Geopolityczna specyfika Batkanów i etniczne terytorium Serbów, „Sprawy Niepodległościowe”, t. III, z. 2/1994, s. 135; Mała Encyklopedia Wojskowa, red. O. Laskowskiego, Warszawa 1930, s. 193.

${ }^{34}$ Cieśnina Otranto była i pozostaje tzw. Bramą Adriatycką, tzn. jest jedynym oknem na Morze Śródziemne z portów byłej Jugosławii (obecnie Chorwacji, Czarnogóry i w mniejszym stopniu Słowenii) oraz Albanii.
} 
Centralnym punktem Półwyspu jest Serbia, przez którą przebiegają najważniejsze lądowe szlaki komunikacyjne. W Belgradzie krzyżują się główne szlaki komunikacyjne: zachodniosawski i północnodunajski. Ku południu prowadzą one doliną Wielkiej i Południowej Morawy do miasta Niš, skąd południowe odgałęzienie wiedzie doliną morawsko-wardarską do Tessalonik (Saloniki), a wschodnie - doliną rzek Nišavy i Maricy do Istambułu i dalej na wschód przez Turcję i Mezopotamię, wychodząc do Azji. Inny szlak łączący Belgrad z Europą Zachodnią stanowi droga biegnąca do Zagrzebia, Lublany i dalej na Nizinę Padańską, skąd z kolei biorą początek szlaki do Szwajcarii i następnie do Francji. W kierunku północnym Belgrad jest połączony z drogami na Węgry i na Słowację. Zaś na północnym-wschodzie od Belgradu prowadzi szlak komunikacyjny, wychodzący na Wołoszczyznę poprzez przełom Dunaju i dalej przez Fokszańskie Wrota na Mołdawię i Ukrainę, czyli w głąb Europy Wschodniej.

Ta tranzytowo-łącznikowa funkcja Półwyspu Bałkańskiego wyróżnia go pod względem komunikacji, gospodarki, geopolityki oraz wpływa na wydarzenia historyczne, procesy etniczne i społeczne Bałkanów.

\section{Państwa i ludność}

W XX wieku Płw. Bałkański podzielony był na kilka państw, które w zależności od aktualnie panującej sytuacji tworzyły samodzielne lub podporządkowane sąsiadom jednostki państwowe. W pierwszej i drugiej dekadzie ${ }^{35}$ ubiegłego stulecia większość państw Półwyspu najpierw kosztem Turcji, a następnie Austro-Węgier powiększyło swoje terytoria. Jednocześnie w wyniku licznych konfliktów militarnych powstawały nowe państwa, czego przykładem może być Albania, która na trwałe związała się z dziejami Bałkanów po wojnach bałkańskich, lub nowe kraje ukonstytuowane po wojnie domowej w Jugosławii.

$\mathrm{Na}$ Bałkanach równie skomplikowane są również stosunki narodowościowe. Obecnie Pólwysep zamieszkuje je około 50 mln. mieszkańców, jednak do pierwszej połowy XX w. obszar ten zamieszkiwało od 20 do $28 \mathrm{mln}$. osób ${ }^{36}$. Pod względem narodowościowym Półwysep stanowił i nadal stanowi mieszankę narodów oraz grup etnicznych. Na tym obszarze spotykamy Albańczyków uważających się za potomków starożytnych Ilirów, Greków, Chorwatów, Słoweńców, Serbów, Bułgarów, Macedończyków, Turków, Kucowołochów ${ }^{37}$, Romów oraz Ormian, Rosjan, Czechów, Słowaków, Żydów oraz Polaków.

35 Właściwie granicznymi są dwa wydarzenia tj. zakończenie I i II wojny bałkańskiej oraz zakończenie pierwszej wojny światowej. Zmieniły one nie tylko stosunek sił na Półwyspie, lecz również mapę granic państwowych.

36 Wielka Geografia Powszechna, Europa IV, Hiszpania, Portugalia, Włochy, Jugosławia..., op. cit., s. 8. W latach trzydziestych Półwysep Bałkański zamieszkiwało ok. 28 mln ludzi.

${ }^{37}$ Kucowołosi to reliktowa grupa etniczna zamieszkująca pogranicze grecko-bułgarsko-macedońskie. Ustalenie dokładnej liczby ludności tej grupy jest niemożliwe. Oblicza się, że w XX w. żyło od 0,1-0,001 mln. przedstawicieli tej społeczności. 
Na początku XX w. sytuacja demograficzna przedstawiała się następująco: Serbów było ok. $2 \mathrm{mln}$, tyle samo ludności liczyła Bułgaria, Czarnogórców było ok. 0,25 mln, Albańczyków ok. 1,2 mln, Węgrów, Turków - ok. 1,6 mln, Niemców i Austriacy ok. $1 \mathrm{mln}^{38}$. Z kolei tuż przed rozpoczęciem działań militarnych w latach 1912-1913 populacja Serbów liczyła ok. 4, 65 mln, Bułgarów - ok. 4,8 mln, Greków - 4, 6 mln, Czarnogórców - 0,5 mln, Albańczyków - 0, $85 \mathrm{mln}$, Turków prawie 1,5 mln, (przy czym dane te dotyczą ludności tureckiej, która zamieszkiwała część europejską tego państwa $)^{39}$, Rumunów ok. $7,5 \mathrm{mln}^{40}$.

\section{Bałkański Teatr Działań Wojennych}

Opisywany obszar geografia wojskowa określa jako Bałkański Teatr Działań Wojennych (dalej: Bałkański TDW) ${ }^{41}$ i stanowi część składową Śródziemnomorskiego TDW. Obejmuje Płw. Bałkański, południową Rumunię oraz europejską cześć Turcji wraz z akwenem Morza Egejskiego ${ }^{42}$. Centralnym obszarem (punktem) Teatru była Serbia, a następnie w szerszym ujęciu - Federacja Jugosławii. Uważa się, że Bałkański TDW do pierwszej dekady XX wieku odgrywał istotną rolą w dziejach Europy. Bałkany były bowiem miejscem licznych powstań i starć pomiędzy koalicjami chrześcijańskimi oraz wojskami tureckimi. Do pierwszej dekady XX w. stanowiły jeden z najistotniejszych elementów ówczesnych stosunków międzynarodowych.

„Kwestia Wschodnia”, stosunki w państwie tureckim, relacje i dążenia narodowe państw bałkańskich przez dziesiątki lat XIX i pierwszej dekady XX w. zajmowały wielkie mocarstwa sprawiając, że wydarzenia rozgrywające się na tym obszarze były wielokrotnie jednym z najważniejszych problemów w stosunkach międzynarodowych. Ponadto geostrategiczne położenie Bałkanów, wpływające na interesy polityczne i gospodarcze wielkich mocarstw powodowało, że wydarzenia zachodzące na Półwyspie były szczególnie pilnie obserwowane w stolicach europejskich. Partykularne cele mocarstw implikowały ich politykę wobec nowych państw bałkańskich, które od drugiej połowy XIX w. były raczej narzędziami „,wielkich” ówczesnego świata niż równorzędnymi partnerami.

Konieczność kontroli głównych szlaków morskich i lądowych biegnących zarówno w obrębie Półwyspu, jak również w otaczających go akwenach mórz:

\footnotetext{
${ }^{38}$ W. Trąmpczyński, Albania i Macedonia. Kraj i Ludzie, Warszawa 1903, s. 7-9.

${ }^{39} \mathrm{~W}$ charakterystyce rosyjskiego historyka Mikołaja Korsuna nie wyodrębniono jako narodowości Słoweńców, Chorwatów oraz Macedończyków. Podano dane dotyczące głównych państw biorących udział w wojnach bałkańskich 1921-1913.

${ }^{40}$ Н. Корсун, Балканский фронт мировой войны 1914-1918 г2., Москва 1939, s. 8.

${ }^{41}$ T. Rawski, Polityka i strategia na Śródziemnomorskim Teatrze Wojny 1939-1940 (próba analizy). Maszynopis, Warszawa 1971, s. 1.

42 Jugosłowianie dokonali jeszcze innego podziału na: północny, środkowy i południowoeuropejski teatr działań wojennych. Zaliczając Bałkany do tego ostatniego, R. Marianković, Opšta vojna geografia, Beograd 1983, s. 24-48.
} 
Adriatyckiego, Egejskiego Jońskiego oraz Śródziemnego, zmuszały państwa, których interesy sięgały poza Bałkany do zwrócenia szczególnej uwagi na wydarzenia zachodzące na tym obszarze. Przykładem może być sprawowanie kontroli nad najkrótszym szlakiem morskim biegnącym przez Kanał Sueski. Dla Francji i Wielkiej Brytanii niezbędnym było nie tylko sprawowanie kontroli nad Maltą i Cyprem, lecz również zabezpieczenie swoich interesów na Bałkanach, bowiem dominacja któregokolwiek z państw tego regionu lub jakiegokolwiek sojuszu nieprzyjaznego wobec mocarstw zagrażała ich żywotnym interesom gospodarczym i politycznym związanym z funkcjonowaniem Kanału Sueskiego. ${ }^{43}$. Strategiczne znaczenie cieśnin tureckich także wywierało zasadniczy wpływ na stosunki międzynarodowe. Walka o swobodny dostęp z Morza Czarnego do Śródziemnego, jakią toczyła Rosja, stała się jedną z podstawowych elementów „kwestii wschodniej” ${ }^{4}$. Rosja, prowadząc wojny i działania dyplomatyczne, starała się stopniowo osłabiać Turcję, aby uzyskać kontrolę nad cieśnina$\mathrm{mi}^{45}$. Kontrola nad Dardanelami i Bosforem stanowiła, bowiem, dla imperium carów „być albo nie być” stając się jedną z newralgicznych kwestii polityki zagranicznej i gospodarczej Rosji w XIX oraz w pierwszych dwóch dekadach XX w. ${ }^{46}$ Cieśniny nabrały szczególnego znaczenia dla Rosji i jej sojuszników wraz z wybuchem I wojny światowej, kiedy Rosja, znajdująca się w konflikcie z Niemcami, Austro-Węgrami, a następnie i Turcją utraciła możliwość komunikacji z Francją. I w ten sposób została odcięta od dostaw sprzętu i materiałów wojennych z tego kraju ${ }^{47}$.

Jak już wcześniej wspomniano, Bałkański Teatr Działań Wojennych obejmuje obszar Serbii, Bośni i Hercegowiny, Czarnogóry, Macedonii, Chorwacji, Słowenii, Albanii, Grecji, Bułgarii oraz częściowo również Rumunii i Słowenii.

Granice teatru działań wyznaczają:

- na północy i północnym - wschodzie: rzeki Dunaj i Sawa aż po Dobrudżę ${ }^{48}$;

- na wschodzie wybrzeże Morza Czarnego aż po cieśniny tureckie;

- na południu i południowym - zachodzie: wybrzeże Morza Egejskiego od Kavali do cieśnin tureckich;

- na zachodzie: wybrzeże Morza Adriatyckiego poprzez chorwackie wybrzeże, dalej wzdłuż wybrzeża Czarnogóry aż po wybrzeże albańskie.

Opisywany Teatr Wojny obejmuje przede wszystkim obszary o ukształtowaniu wyżynnym i górskim z niewielkim pasami nizin, występującymi głównie w dolinach rzek. Zachodnia część Teatru pokryta jest górami należącymi do pasma dynarskiego i Pindu. Również w części wschodniej występują liczne pasma górskie:

43 M. Tanty, Konflikty batkańskie w latach 1878-1918, Warszawa 1968, s. 16.

${ }^{44}$ M. Tanty, Bosfor i Dardanele w polityce mocarstw, Warszawa 1982, s. 6

45 T. Wituch, Terytoria sporne w Europie po roku 1815, Pułtusk 2001, s. 61.

${ }^{46}$ M. Tanty, Rosja wobec wojen batkańskich 1912-1913 roku, Warszawa 1970, s. 38; M. Herma, Pod banderq św. Andrzeja. Rola Floty Czarnomorskiej w realizacji koncepcji strategicznych (militarnych) Rosji w latach 1914-1917, Kraków 2002, s. 7-8.

${ }^{47}$ M. Tanty, Bosfor i Dardanele..., op. cit., s. 302-310.

48 Według pewnej grupy geografów (o czym wspomniano w części wstępnej) również Rumunia powinna być zaliczana do państw Półwyspu Bałkańskiego. 
Góry Bałkańskie i masyw Rodopów. Natomiast w północno-wschodniej części rozciagają się Karpaty. Cechą charakterystyczną Alp Dynarskich i Pindu pokrywających Chorwację, częściowo Bośnię, Serbię, Czarnogórę, Grecję i Albanię ${ }^{49}$, jest ich ograniczona dostępność, związana ze znaczną wysokością oraz budową geologiczną. Z dużego węzła górskiego Szar-daga, gdzie zbiegają się pasma górskie, odchodzi na wschód pasmo górskie Bałkanu (zw. też Starą Planiną; staroż. Aemon Haemus) ${ }^{50}$. Dzieli on Bułgarię na dwie części: północną i południową, rozciąga się (na obszarze Bułgarii i Serbii), tworząc łuk wygięty ku południowemu zachodowi od doliny Dunaju (przełom Żelaznej Bramy) sięgając po wybrzeże Morza Czarnego. Pasmo Bałkanu dzieli się na: Zachodnią Starą Planinę (Bałkany Zachodnie), dochodzącą do Przełęczy Zlatnickiej; przeciętą głęboką doliną rzeki Iskyr; Wysoką Starą Płaninę (Bałkany Środkowe) - do przełęczy Vratnik; Wschodnią Starą Płaninę (Bałkany Wschodnie $)^{51}$. Na tym obszarze przeważa rzeźba o charakterze średniogórskim, ze spłaszczonymi wierzchołkami oraz rozczłonkowanymi głębokimi dolinami.

$\mathrm{Na}$ zachód od góry Sofin, Góry Bałkańskie oddzielają w kierunku południowo -wschodnim trudno dostępny Masyw Rodopski, co sprawia, że południowa strefa górskiej granicy serbsko-bułgarskiej stanowi obszar niesprzyjający do prowadzenia operacji wojskowych siłami dużych jednostek zmechanizowanych.. Obszar ten ze względu na swoje ukształtowanie sprzyja natomiast prowadzeniu działań nieregularnych, zwłaszcza wojny partyzanckiej.

Rodopy dzielą Teatr na dwa rejony, wschodni (Tracja) i zachodni (Macedonia i Albania).

Klimat Na Bałkanach występują strefy klimatyczne oscylujące między umiarkowanie ciepłą na północy a podzwrotnikową na południu. Występuje tam także klimat górski z wpływami kontynentalnymi. Roczna suma opadów od $1500 \mathrm{~mm}$ na zachodzie do 500-600 mm na wschodzie.

Hydrografia. Największe znaczenie w granicach Teatru mają rzeki Dunaj i jego dopływ Sawa, która z kolei przyjmuje wody Driny. Środkową część rozpatrywanego Teatru przecinają rzeki: Morawa, Wardar i Struma. Pierwsza z nich należy do zlewiska Dunaju wpadającego do M. Czarnego, pozostałe uchodzą do M. Egejskiego.

W masywie Bałkanu mają swe źródła rzeki: Tundża (dorzecze Maricy), Nišawa, Timok, Ogosta, Jantra (dorzecze Dunaju), a także Kamczija. Pozostałe rzeki w granicach Teatru także stanowią naturalną przeszkodą utrudniającą manewr - mogą podczas wylewów albo rozdzielić ugrupowanie bojowe, albo stanowić dogodne rubieże obronne.

Zatoki. Na wybrzeżu Morza Egejskiego należy wymienić Zatokę Salonicką wraz z portem, która stanowi rozległy akwen umożliwiającym swobodny dostęp oraz manewr dużymi zespołami marynarki wojennej. Posiada przestronny i dobrze ulokowany

\footnotetext{
49 Albańczycy nazywają swoją ojczyznę ,krajem skał”.

${ }^{50} \mathrm{~W}$ literaturze przedmiotu spotykamy się również z nazwą Góry Bałkańskie lub Góry Bałkan.

51 Część geografów wydziela Góry Wschodnioserbskie. Inni natomiast uważają, iż pasmo to powinno być zaliczone do masywu Bałkanu.
} 
geograficznie port Saloniki. Na wybrzeżu M. Adriatyckiego do najdogodniejszych zatok należy zaliczyć: San Giovanni de Medua, Durazzo, Valona i Santi Cvaranta, Split.

Wybrzeże M. Egejskiego oraz Adriatyku charakteryzuje się dużą liczbą wysp, spośród których wymienić należy Korfu i Kretę oraz wyspy Morza Adriatyckiego. Ich położenie sprawia, że mogą one stanowić dogodne punkty wyjściowe do prowadzenia działań na kilku kierunkach.

\section{Komunikacja i szlaki strategiczno-operacyjne}

Bardzo istotne znaczenie posiadały magistrale Belgrad - Konstantynopol i Belgrad - Saloniki ${ }^{52}$, a ponadto na wschodnim froncie droga Kirki-Kilise - Adrianopol Lüleburgaz - Konstantynopol. Przez Bałkany prowadziły linie kolejowe: Sofia-Ruse, Ruse-Drianowo-Podkowa oraz Karnobad-Komunari.

Położenie pasm górskich na Półwyspie względem osi prowadzonych działań powodowało wygenerowanie najlepszych kierunków uderzeń, do których należy zaliczyć:

a) kierunek północno-zachodni, północ- południe i południowo- północny

- Belgrad - Niš - Saloniki;

- od rzeki Driny na Belgrad-Kruševac;

- z kierunku zachodniego przez Bramę Lublańską na Belgrad;

b) kierunek wschód-zachód

- od rzeki Timok ku dolinom rzeki Moravy;

- od rzeki Strumy ku rzece Vardar ${ }^{53}$.

c) kierunek południe-północ

- Saloniki-Veleš-Belgrad;

- Saloniki-Veleš (lub Uskub)-Sofia, a dalej na Adrianopol-Konstantynopol lub przez Plewnę w kierunku Dunaju.

d) kierunek północ-południe oraz północ-południowy zachód

- Niš-Uskub-Veleš-Saloniki;

- przez Albanię ku portom: St. Giovanni de Medua, Durazzo, Valona.

\section{Ludność}

Według statystyk tureckich, w europejskiej części Turcji żyło 1300 tysięcy Turków (z czego 400 tys. zamieszkiwało w Konstantynopolu i mniej więcej tyle samo

52 Н. Корсун, Балканский фронт мировой войны 1914-1918 г2., Москва 1939, s. 121-122.

${ }^{53} \mathrm{Na}$ tym kierunku prowadziły działania militarne wojska bułgarskie podczas II wojny bałkańskiej, a następnie w 1915 r. podczas operacji przeciwko Serbii oraz niemieckie w kwietniu 1941 r. w ramach operacji nr 25 (rozszerzenie planu „Marita”). Wzdłuż biegu rzek Moravy i Vardaru, w kierunku z północy na południe rozciagają się doliny połączone między sobą drogami co stanowi jedyny dogodny szlak do prowadzenia działań wojennych w tym obszarze. 
na wyspach), Bułgarów - 2100 tys., Greków do 1 mln (wraz z wyspami), Serbów 500 tys., Albańczyków -800 tys., Żydów -90 tys., Rumunów -70 tys ${ }^{54}$.

Na omawianym obszarze, na którym toczyły się działania wojenne do 1912 r. zamieszkiwało wg różnych szacunków ok. 61/2 miliona mieszkańców, którzy reprezentowali narodowości panstw wchodzących w skład koalicji. Przedstawiciele narodu, który dokonał podboju tych ziem - Turcy, byli rozproszeni na wymienionym obszarze, z czasem jednak zasymilowali się z lokalnym społeczeństwem. Nie stanowiąc nawet piątej jego części, zamieszkiwali przeważnie miasta. W Albanii w omawianym okresie występowało największe zróżnicowanie pod względem językowym oraz wyznaniowym.

Według statystyk tureckich Turków w jej europejskiej części Europie żyło 1300 tysięcy (z czego 400 tys. zamieszkiwało w Konstantynopolu i mniej więcej tyle samo na wyspach), Bułgarów - 2100 tys., Greków do $1 \mathrm{mln}$ (wraz z wyspami), Serbów - 500 tys., Albańczyków - 800 tys., Żydów - 90 tys., Rumunów - 70 tys ${ }^{55}$.

\section{Wschodni Teatr Operacyjny}

Wschodni Teatr Operacyjny ${ }^{56}$ na zachodzie ogranicza masyw Rodopów, który odgradza Trację od Macedonii, natomiast jego wschodnią granicę stanowi wybrzeże M. Czarnego. Pomiędzy wzniesieniami Strandży i Rodopów rozpościera się dolina rzeki Maricy, która była (i nadal pozostaje) jedynym szlakiem z Bułgarii, od dolnego Dunaju do Bosforu.

Manewr wojsk w tym rejonie możliwy jest tylko doliną rz. Maricy, która jedynie poniżej Adrianopola jest zdatna do żeglugi i jednocześnie mało dogodna do pokonania jej w bród, w związku ze znaczną szerokością (do 300 m). Od Demotiki Marica skręca na zachód i dalsza droga w kierunku Bosforu biegnie doliną rzeki Ergene, która jest dopływem Maricy. Drugą rzeka, mającą wpływ na działania militarne w omawianym rejonie jest Tundża, która spływa ze wschodniego Bałkanu, stanowiąc dogodne dojście do doliny Maricy z kierunku północnego. Dolina Ardy z kolei stanowi najkrótsze połączenie z Morzem Egejskim.

Jesienią koryta rzek wskutek obfitych opadów wywoływały liczne powodzie, w związku z czym brody stawały się nie do pokonania (a mostów w omawianym okresie praktycznie nie było). U ujścia Tundży i Ardy do Maricy znajduje się jeden z najważniejszych punktów strategicznych północnej Tracji - Adrianopol. Tu właśnie owymi trzema dolinami biegły też najważniejsze szlaki i drogi teatru (szosa z Filippopola na Adrianopol i dalej na Konstantynopol, droga Jambol - Adrianopol).

\footnotetext{
${ }^{54}$ Н. Корсун, Балканский фронт..., s. 122-123.

55 Ibidem.

56 Teatr Operacyjny lub teatr działań operacyjnych czyli część teatru działań strategicznych, na którym są prowadzone działania o charakterze operacyjnym bądź operacyjno-strategicznym, R. Marianković, Opšta vojna..., op. cit., s. 32-33, 231 et passim.
} 
Brzeg czarnomorski z Morzem Marmara od Sizopola na Kirk - Kilise (Lozengrad) Lüleburgaz do Rodosto połączony jest drogą rokadową. Szosa Kirk - Kilise - BunarHissar - Wiza - Saraj - Czorlu stanowi bezpośrednie połączenie wschodniej Bułgarii z Konstantynopolem ${ }^{57}$.

Ważnymi punktami strategicznymi dla wojsk operujących na Wschodnim Teatrze Operacyjnym były:

- Adrianopol (Odrin) - węzeł dróg północnej Tracji. Posiadł rozbudowane fortyfikacje złożone z umocnień pochodzących z drugiej połowy XIX w. oraz wybudowanych na początku dwudziestego stulecia ${ }^{58}$.

- Kirk-Kilise (j. bułg. Lozengrad) - umocniona pozycja pod Lozengradem ryglowała ruch z kierunku Sizopola i południowo-wschodniej Bułgarii w kierunku doliny Maricy i dalej do Bosforu i Morza Marmara ${ }^{59}$.

- Linia Czataldży usytuowana w wąskim przesmyku pomiędzy M. Czarnym i M. Marmara. była linią fortyfikacji stałych i ziemnych. ${ }^{60}$.

- Konstantynopol (Istambuł, Stambuł) był ostatnim bastionem obrony oraz zapleczem dla walczących w Tracji Wschodniej armii tureckich ${ }^{61}$.

- Cieśnina Dardanele, zamykająca wyjście z Morza Marmara na wody M. Egejskiego i osłaniająca Konstantynopol przed atakiem floty potencjalnego przeciwnika - od M. Egejskiego. Posiadała istotne znaczenie dla prowadzenia operacji morskich jak również morsko-lądowych i lądowych. Dzięki fortyfikacjom zbudowanym na półwyspie Gallipoli stanowiła newralgiczny punkt dla systemu obronny Porty ${ }^{62}$.

\section{Macedoński Teatr Operacyjny (Zachodni)}

Zachodni Teatr Operacyjny rozciagga się pomiędzy morzami: Egejskim i Adriatyckim, Bułgarią, Serbią, Czarnogórą i Grecją, obejmując tereny wchodzące niegdyś w skład starej Bułgarii (część Macedonii), Serbii (Stara Serbia), Greckiego Bizancjum (zasiedlone przez Greków południowe wybrzeże i miasta nadmorskie położone nad Morzem Egejskim), a także Albanię ${ }^{63}$.

${ }^{57}$ Н. Корсун, Балканский фронт..., s. 123-124.

58 Н. Ивановъ, Балканската война 1912-1913 год. Дествияата на ІІ Армия, обсада и атака на одринската крепостъ, София 1924, s. 21-24

${ }^{59}$ Н. Корсун, Балканский фронт..., s. 124.

${ }^{60}$ И. Дроговоз, Туреикий марш. Туречия в огне сражений, Минск 2007, s. 69.

${ }^{61}$ Н. Корсун, Балканский фронт..., s. 125.

62 Ibidem, s. 125-126.

63 Bazą do działań w rejonie zachodnim dla armii osmańskiej w 1912 r. mogła być tylko Małoazjatycka Turcja, gdyż przy nielicznej własnej ludności tureckiej, braku źródeł zaopatrzenia kwatermistrzowskiego dla armii w postaci zarówno środków bojowych, jak i żywności, armia turecka nie mogła liczyć na lokalne zaopatrzenie. 
Albania jest krajem górzystym i tylko w pasie nadmorskim występują nieliczne niziny ${ }^{64}$. Góry, które wznoszą się na terytorium Albanii, stanowią południowe przedłużenie łańcucha Gór Dynarskich. Poprzecinane dolinami rzek płynących wyłącznie do M. Adriatyckiego. Tworzą one szereg grzbietów i pasm rozpościerających się z północy na zachód i z południa na wschód. $\mathrm{W}$ wielu miejscach rozciętych dolinami o przebiegu równoleżnikowym.

Na północy Albanii od pogranicza serbskiego usytuowane są Alpy Albańskie zwane też Górami Przeklętymi. Są one, jak pozostałe pasma usytuowane w głębi kraju, dzikie i niedostępne, przeważnie bezleśne ${ }^{65}$. Między Drinem i Osum wznoszą się Góry Środkowoalbańskie. Południową część Albanii zajmuje Epir Albański. W tej części występują także zjawiska krasowe.

W obrębie Gór Środkowoalbańskich leży Kotlina Korczy, która jest największą kotliną Albanii. Jej dno spoczywa na wysokości ok. 800 m n.p.m. Wzdłuż granicy z Macedonią rozciagga się masyw Koraba. Innym pasmem górskim, które występuje na obszarze Albanii, jest Šar Planina (alb. Malet e Sharrit). Rozciaga się ono na terytorium północno-wschodniej Albanii i północno-zachodniej Macedonii. Na północy graniczy z Górami Dynarskimi, na południu natomiast dotyka gór Pindos.

Niziny skupiają się w pasie nadbrzeżnym. Strefę nadmorską zajmuje Nizina Albańska. Linia brzegowa Albanii jest dobrze rozwinięta, występują tam liczne, szerokie i głębokie, wcięte w ląd zatoki.

Obszar Albanii, z wyjątkiem wąskiego odcinka wybrzeża, jest niedogodny do prowadzenia dużych operacji, zwłaszcza z użyciem znacznych sił. Niewielka ilość dróg przy trudno dostępnych pasmach górskich, podobnie jak w innych regionach omawianego obszaru, powodowała znaczne trudności w planowaniu oraz organizacji działań. Teren ten nadaje się do prowadzenia walki w górach $\mathrm{z}$ udziałem jednostek górskich, specjalnych oraz oddziałów partyzanckich. Jest również dogodny do organizowania zasadzek oraz blokowania nielicznych szlaków komunikacyjnych. Z kierunku północnego i południowego jest natomiast prawie niedostępny. Jedyną możliwość prowadzenia manewru stwarzają doliny rzek, jednak pod warunkiem, że nie zostaną zaminowane. Tylko kierunek wschodni umożliwia dostęp w głąb Albanii, a następnie poprzez Kosovo Polje w głąb Półwyspu. Z kolei kierunek zachodni, z podstawą wyjściową którą stanowią: akwen M. Adriatyckiego oraz wybrzeże albańskie, umożliwia prowadzenie na ograniczoną skalę operacji morsko-lądowych.

W zachodniej części Teatru płynie doliną Czarny (Crni) Drin, który łączy się z Białym Drinem (Beli Drin), tworząc najdłuższa rzekę Albanii - Drin $^{66}$. W dolinie Drinu biegnie droga łącząca serbskie i macedońskie szlaki komunikacyjne, prowadzące ku zatokom Adriatyku (Zatoka San Giovanni-di-Medua, Allesio, Durazzo).

64 Wielka Geografia Powszechna, Europa IV, Hiszpania, Portugalia, Włochy, Jugostawia..., op. cit., s. 128.

65 Ibidem.

${ }^{66}$ Ibidem, s. 129. 
Jednym z ważniejszych szlaków komunikacyjnym w tym rejonie była szosa VranjiaPriština-Prizren, osłaniana przez twierdzę Skutari ${ }^{67}$.

Czarny Drin stanowił również granicę etnograficzną pomiędzy ludnością serbską zamieszkującą obszar położony na wschód od tej linii a ludnością albańską mieszkającą na zachód od Cz. Drinu. (ok.)

Południową część Teatru stanowią Epir i Tessalia, będące obszarem górzystym z nielicznymi szlakami komunikacyjnymi. Na omawianym obszarze znajdują się zasadniczo dwa najważniejsze kierunki operacyjne:

- pierwszy z nich biegnący z greckiej Tessalii w kierunku Elasson-KožaniMonastyr i stąd na Katerinę, wzdłuż brzegu morza na Saloniki.

- drugi kierunek prowadzi z doliny Arty na Janinę ${ }^{68}$.

Punkt spajający Wschodni i Zachodni Teatr stanowiło miasto Saloniki. Warunkiem zachowania łączności pomiędzy oboma Teatrami było utrzymanie kontroli nad Macedonią oraz zapewnienie przez Turcję przewagi na morzu.

Macedonia, Kosovo i Metohija stanowiły centralnąi wschodnią część Zachodniego Teatru Działań. Należy zaznaczyć, że obszar, na którym prowadzono działania w toku Wojen bałkańskich jest znacznie większy niż współczesna Republika Macedonii.

Macedonia położona jest pomiędzy Morzem Egejskim na południu i pasem Šar Planiny na północy. Z kolei na zachodzie ograniczają ją pasma Gór Dynarskich, zaś na wschodzie masyw Rodopów ${ }^{69}$. Między masywami leżą kotliny - Prilepsko Polje w dolinie Crnej Reki, Polog Polje (Pelagonija) w dolinie górnego Vardaru, Ovče Polje i Kočansko Polje nad Bregalnicą oraz doliny rzek - Strumicy, Vardaru i Drinu ${ }^{70}$.

Jednym z najważniejszych obszarów jest Polog Polje (Pelagonija), które rozciagga się na północy od Prilepska do Bitolskiego Polja na południu. Na zachodzie Macedonii, wzdłuż granicy z Albanią, leży pas wapiennych Dynarów albańskich. Na wschód od Jeziora Prespa występuje Bigla Planina, zaś na południe znajduje się Resenska Kotlina, którą od zachodu ogranicza Wschodnia Planina, a od północy Plakenska Planina, przez którą biegnie szlak łączący Bitolę z Ochrydą i Strugą ${ }^{71}$.

Na wschód od doliny Vardaru rozciagga się Macedonia Wschodnia poprzecinana górami i dopływami Vardaru oraz płaskowyżami, na czele z Ovćim Poljem. Środkowa część Macedonii jest w przeważającej części obszarem górzystym, rozdzielonym doliną Vardaru. Dolina ta utworzona jest najpierw przez Kotlinę Tetowska, następnie przechodzi w Kotlinę Kumanowską, dochodząc do obecnych granic Grecji ${ }^{72}$.

${ }^{67}$ Н. Корсун, Балканский фронт..., s. 127.

$68 \mathrm{Na}$ drugim kierunku istniały stare tureckie umocnienia twierdzy Prewieza, rozlokowanej u wejścia do Zalewu Artskiego, fort Nikopol na północ od Prewiezy i słabo umocniona pozycja pod Pendepigadii położona na przejściu z doliny Arty ku Janinie, czyli do centrum tureckiego Epiru. Za namową von der Goltza, Turcy zaczęli przekształcać Janinę w silną twierdzę, która miała stanowić podstawę do działan tureckich w rejonie teatru operacyjnego.

${ }^{69}$ I. Stawowy-Kawka, Historia Macedonii, Wrocław-Warszawa-Kraków 2000, s. 5.

${ }^{70}$ D. Gibas-Krzak, A. Krzak, Poludniowostowiańska Mozaika. Charakterystyka geograficzno-polityczna państw postjugostowiańskich, Szczecin 2010, s. 132.

${ }^{71}$ I. A. Božič, M. A. Knežević, Osnovi Vojne Geografije..., s. 153.

72 D. Gibas-Krzak, A. Krzak, Potudniowostowiańska Mozaika..., s. 133. 
Doliną rzeki Vardar biegnie jeden z najstarszych i najważniejszych szlaków komunikacyjnych łączących poprzez Belgrad Europę Zachodnią i Północną z Azją Mniejszą. Tutaj koncentrują się też inne drogi: pierwsza z nich, przecinająca dolinę Ibaru, biegnie przez Kosovo Polje i Kačanički Wąwóz, inna natomiast łączy Jezioro Ochrydzkie przez Kotlinę Kičevską z Pologiem. Kolejnym, bardzo ważnym połączeniem, jest szlak komunikacyjny rozciagający się od Krivej Polanki przez Kumanovo do Štipu. Najważniejszym ośrodkiem miejskim w dolinie Vardaru jest Skopje $(\text { Skoplje) })^{73}$.

Górny bieg rzeki Vardar znajduje się w sąsiedztwie dorzeczy rzek: Dunaj-Drina, Ibaru, Moravy, Iskieru. Dolinami wymienionych rzek biegną trzy wewnętrzne szlaki z Bośni, Serbii i Bułgarii:

- z Bośni na Mitrovicę;

- z Serbii linia kolejowa Belgrad - Niš - Kumanovo;

- z Bułgarii od górnego biegu Iskieru od Sofii do Kijustendił.

Kosowo leży na zachodzie, na styku Gór Dynarskich, natomiast na wschodzie sięga do pasma Bałkanów. Na północy i wschodzie od Serbii oddzielają Kosowo pasma Rogozny, Kopaonika oraz Goljaka, zaś na południu pasma Crnej Gory i Šar Planiny stanowiące granicę z Macedonią. Na północnym zachodzie i zachodzie rozciąga się pasmo Gór Północnoalbańskich (Alp Albańskich). Wnętrze Kosowa, podzielone przez masyw Crnoljeva Planina, składa się z dwóch głównych jednostek geograficznych, które stanowią: Metohija i Kosovo Polje.

Metohija (Metochija, Metohija Polje) Od północy graniczy z pasmem Mokrej Gory, zaś na północy i północnym zachodzie z Górami Północnoalbańskimi, a na południu sięga po masyw Šar Planiny ${ }^{74}$. Na północnym jej skraju znajduje się miasto Peć. Z kolei na południowym przedłużeniu Metohiji u podnóża Šar Planiny leży Prizren.

Kosowo Polje ciaggnie się od miasta Zvečan na północy do Kačanika na południu. Otoczone jest od zachodu rzeką Toplugą oraz na południu i południowym-wschodzie rzekami: Sitnicą i Nerodimką.

Oba polja dzieli dolina rzeki Drenicy i masyw Crnoljeva Planina, który jest ograniczony dolinami rzek Drenicy i Topi. Przez Przełęcz Dulijską prowadzi najkrótsza droga z Prištiny do Prizrenu, natomiast poprzez przełęcz Goleś biegną drogi: PrištinaPeć oraz Orehovac-Lapušnik-Priština.

Šar Planina to pasmo górskie ciągnące się wzdłuż granicy z Macedonią i Albanią. Po stronie Kosowa jest strome, zaś od Macedonii występują łagodne zbocza. W dolinach występują liczne, ale zarazem małe jeziora polodowcowe. Pomimo znacznej wysokości i pozornej niedostępności, pasmo Šar Planiny nie stwarza problemów dla komunikacji, bowiem między szczytami Ljuboten i Skopska Crna Gora leży wąwóz Kačanik, który tworzy naturalne przejście z Kosowa w głąb Macedonii ${ }^{75}$.

\footnotetext{
73 Ibidem.

74 Ibidem, s. 173.

75 Ibidem, s. 174.
} 
Kopaonik jest masywem górskim biegnącym z południa na północ. Od wschodu graniczy z Doliną Ibaru, jednak tylko część łańcucha Kopaonika, podobnie jak Alp Północnoalbańskich, znajduje się na obszarze prowincji kosowskiej ${ }^{76}$.

\section{Ocena przygotowań tureckich do wojny na Zachodnim i Wschodnim Teatrze Operacyjnym}

Turcy, przygotowując się do wojny, nie umacniali omawianego rejonu na wypadek prowadzenia działań obronnych, tak jak należało to uczynić. Oprócz silnej ze względu na swoje położenie twierdzy Scutari i nowej twierdzy - Janiny nieukończonej przed rozpoczęciem działań, nie zdołali rozbudować umocnień polowych zdolnych na dłużej zatrzymać nacierające wojska. Również fortyfikacje osłaniające Saloniki nie zostały wzmocnione, chociaż miasto i port stanowiły jeden z najbardziej newralgicznych punktów systemu wojskowego Zachodniego Teatru. Jedyne prace jakie poczyniono, polegały na wzmocnieniu system strażnic wzdłuż granicy z Czarnogórą i Serbią, między innymi budowano dodatkowe umocnienia polowe, które zostały obsadzone przez załogi Albańczyków wywodzącymi się z klanów wiernych Turkom.

Dowództwo tureckie nie zabezpieczyło procesu rozwinięcia i uzupełniania wojsk. Nie przewidziano bowiem, że duża część rezerwistów nie stawi się w punktach koncentracji i jednostkach. Tureckie władze wojskowe liczyły, że ich jednostki zostaną uzupełnione przez oddziały przybywające z Azji Mniejszej. Tą drogą też Armia Otomańska miała otrzymywać środki bojowe. O ile Armia Wschodnia mogła liczyć zarówno na uzupełnienia, jak i na dostarczenie zaopatrzenia z Konstantynopola oraz terenu Tracji Wschodniej, to Armia Macedońska praktycznie została pozostawiona własnemu losowi. Zróżnicowana struktura narodowościowa Macedonii, nieprzychylny stosunek części klanów albańskich musiały mieć negatywne konsekwencje dla mobilizacji.

Ponadto lokalne możliwości Teatru w zakresie wyżywienia armii były znaczne, gdyż jego obszar obejmował znaczny areał ziemi uprawnej, który powinien wyżywić nawet milionową armię. Struktura własnościowa oraz polityka wewnętrzna Turcji spowodowały jednak, że Turcy nie mogli liczyć na stałe dostawy żywności. Ponadto brak przemysłu zbrojeniowego na obszarze Teatru nie pozwalał na wyprodukowanie środków niezbędnych do prowadzenia walki. Jeśli do tego dodamy niedostatek zapasów oraz przerwanie szlaków komunikacyjnych, to okaże się, że armia turecka przegrała kampanię jeszcze zanim ją rozpoczęła.

\section{Zakończenie}

Ukształtowanie Półwyspu Bałkańskiego (rzeźba Wschodniego i Zachodniego Teatru Działań Operacyjnych) w znacznym stopniu wpływało na charakter pro-

\footnotetext{
${ }^{76}$ Ibidem.
} 
wadzonej walki. Implikowało nie tylko dobór głównych i pomocniczych kierunków natarcia, ale też możliwości koncentracji wojsk, przerzutu oraz zabezpieczenia materiałowego, a w dalszej perspektywie również osobowego uzupełniania wojsk. Niezbędne było zatem przeprowadzenie studiów terenu, co zrealizowali tylko Serbowie i Bułgarzy. Ich przeciwnicy, Turcy, uważali natomiast, iż informacje, które posiadają, są w pełni wystarczające do prowadzenia operacji na opisywanym obszarze. Jednym z najpoważniejszych błędów popełnionych przez Turków było niedocenienie możliwości mobilizacyjnych wojsk koalicji. Kolejnym był kompletny brak danych o infrastrukturze wojskowej, zwłaszcza Bułgarii, następnym zaś nieprzygotowanie po swojej stronie terenu do walki. Odrzucenie defensywnego, na rzecz ofensywnego, planu prowadzenia operacji stało się przysłowiowym „gwoździem do trumny" dla tego państwa.

Odrzucenie koncepcji wypracowanych przez niemieckich doradców reformujących osmańską armię można ocenić jako zupełnie niezrozumiałe posunięcie. Wydaje się, że wypływało ono z pozbawionego racjonalnych przesłanek przekonania dowódców i sztabowców tureckich, iż uda im się w krótkim czasie pokonać wojska Ligi, dysponując stosunkowo nieznacznymi siłami. Ten pogląd wskazuje na to, że Turcy nie znali potencjału swoich przeciwników, nie wiedzieli, że od dłuższego czasu przygotowywali się do rozprawy z Portą. Prace fortyfikacyjne dokonane w latach 1910-1912 w twierdzy Adrianopolskiej oraz zapoczątkowanie budowy umocnień w rejonie Lozengradu, (miała powstrzymać pierwsze uderzenie wojsk bułgarskich i dać Turcji niezbędny czas do zakończenia mobilizacji) nie wpłynęły znacząco na poprawę sytuacji wojsk tureckich $\mathrm{w}$ tym rejonie.

Innym, istotnym czynnikiem dla prowadzenia działań wojennych były warunki atmosferyczne. O ile w I fazie konfliktu sojusznicy starali się utrzymać zaopatrzenie wojsk na odpowiednim poziomie, to w kolejnych było już znacznie gorzej. Wydłużenie linii szlaków dostaw spowodowało znaczne utrudnienia w dostarczaniu na front amunicji i żywności. Bułgarzy i Serbowie zapomnieli, iż warunki atmosferyczne wpływają nie tylko na szybkość marszu czy dostarczanie zaopatrzenia, ale również na stan zdrowia i morale wojska. Katastrofalna sytuacja sanitarno-higieniczna z pewnością oddziaływała na liczbę zachorowań i efektywność podejmowanych operacji. Opady śniegu w lutym 1913 r. ${ }^{77}$ w ogóle uniemożliwiły prowadzenie jakiejkolwiek walki.

Z kolei nacierający, czyli państwa Ligi Bałkańskiej, musieli dostosować swoje plany do warunków terenowych, w jakich przyszło im działać. Dużą rolę odegrały rozpoznanie i działania wywiadowcze, zwłaszcza te, które zostały przeprowadzone przed wojną. Specyfika ukształtowania Bałkanów nie pozwalała planistom na wykorzystanie innych szlaków i osi operacyjnych niż te, które były wykorzystywane od wieków. Dlatego też Bułgarzy poprowadzili część swoich związków taktycznych przez bezdroża Strandży, zaskakując Turków i wprowadzając do walki aż trzy armie.

\footnotetext{
77 Wraz z spadkiem temperatury poniżej 20 stopni doszło m. in. do nawrotu epidemii chorób zakaźnych.
} 
Tymczasem wg tureckiego rozpoznania w Tracji spodziewano się, że Bułgarzy będą prowadzili działania dwoma związkami operacyjnymi (armiami). Znając ukształtowanie terenu, wykorzystując własną infrastrukturę, która była rozbudowywana z myślą o przyszłej wojnie, udało się koalicjantom szybko i sprawnie przeprowadzić mobilizację. Dzięki temu udało im się zachować inicjatywę zarówno w skali strategicznej, operacyjnej, jak i taktycznej.

Jak już wspomniano, sojusznicy w I fazie nie mieli problemów z zaopatrzeniem wojsk. Wykorzystali w tym zakresie zarówno własne możliwości, jak i drogi, które kontrolowali na wyzwolonym terytorium. Wiedząc, jakie znaczenie dla Turcji ma szlak komunikacyjny Saloniki - Konstantynopol, w stosunkowo krótkim czasie udało im się przerwać to połączenie, izolując Armię „Macedonia”. Błędem było natomiast pozostawienie twierdzy Adrianopol na zapleczu walczących armii bułgarskich. W efekcie końcowym doprowadziło to do załamania ofensywy bułgarskiej na linii Czataldży. W ten sposób pogrzebano możliwość zdobycia Konstantynopola i zrealizowanie strategicznego celu, o jakim marzył król bułgarski, czyli zdobycia stolicy państwa tureckiego.

Należy podkreślić, że Półwysep Bałkański ze względu na swoje specyficzne położenie oraz rzeźbę terenu stanowi niezwykle ciekawy obiekt badań nad konfliktami militarnymi. Na podstawie doświadczeń wynikających z wojen bałkańskich i innych antagonizmów, jakie się rozegrały na Półwyspie w ubiegłym wieku, można stwierdzić, iż badania prowadzone nad znaczeniem tego obszaru mogą stanowić podstawę wyjściową do wypracowania rozwiązań udoskonalających taktykę w zakresie wykorzystania różnych form działań bojowych realizowanych w specyficznym terenie, jakim są góry. Teren i powiązane z nim elementy będą bowiem zawsze decydowały o doborze narzędzi i środków do prowadzenia wojen.

\title{
BALKAN PENINSULA AS THE AREA OF MILITARY OPERATION DURING BALKAN WARS. GEOGRAPHICAL-MILITARY CHARACTERISTICS
}

\author{
Summary
}

The Balkan peninsula on account of its peculiar location and the terrain constitutes the unusually interesting object of the research on military conflicts. Forms of operations applied in conflicts, which took place in the range border of the geographical-political Balkans, let read wars run in this area in the course of a few hundred years. Based on experience resulting from the conflicts of Balkan and other antagonisms, which occurred on the Peninsula during the last century, it is possible to state that the conducted research on meaning of this area can constitute the initial base to next research on Balkan military conflicts. Furthermore, the terrain and its components always serve as a toll to pinpoint the indispensable measures to conduct the wars. 